\title{
The Metaphorical Perceptions of Teacher Candidates Attending the Pedagogical Formation Program on Academic Staff_-Gazi University Sample
}

\author{
A. Selcen Arslangilay ${ }^{1} \&$ Mehmet Taşpınar $^{1}$ \\ ${ }^{1}$ Educational Sciences Department, Gazi Faculty of Education, Gazi University, Ankara, Turkey \\ Correspondence: A. Selcen Arslangilay, Educational Sciences Department, Gazi Faculty of Education, Gazi \\ University, Teknikokullar, 06500 Ankara, Turkey. E-mail: aslihanselcen@yahoo.com
}

Received: April 17, 2017

Accepted: June 3, $2017 \quad$ Online Published: October 28, 2017

doi:10.5539/ies.v10n11p33

URL: https://doi.org/10.5539/ies.v10n11p33

\begin{abstract}
Teacher training in Turkey has a long history with various practices. It has taken a different dimension with training teachers through pedagogical formation program certificates that last for a short time. The aim of this research is to reveal the metaphors of teacher candidates attending pedagogical formation program towards the academic staff. The research was designed with qualitative model and phenomenology design was used. The sample of the study group was composed of 392 teacher candidates. Teacher candidates were asked to fill in the sentence; "Academic staff during the pedagogical formation program is like .......; because ..................". The data analysis was conducted with qualitative methods. The academic staff is described in 11 basic categories. Most of these categories are made of positive behaviors composing $86.47 \%$ as guiding, advisor and counselor, the resource of knowledge and experience, constructive and developer, multi-perspective, self-developing, open to change, respectful, patient, tolerant and democratic, role model, using effective body language and presentation techniques. The remaining 4 categories are made of metaphors presenting the negative behaviors of academic staff reflecting $14.03 \%$ of teacher candidates: just narrating, not communicating enough, authoritative and oppressive, behaving inconsistently and irresponsive, non-communicative and with high ego.
\end{abstract}

Keywords: academic staff, metaphor, pedagogic formation program, teacher candidates.

\section{Introduction}

\subsection{Problem Statement}

Teacher training in Turkey has a long history with various practices. Yet, today teachers are mainly trained in Faculties of Education. In these faculties, teacher candidates take education in three dimensions such as field knowledge, pedagogical formation and general culture courses. However, there are some other practices such as pedagogical formation programs that offer certificates for those who want to be a teacher and did not study in a Faculty of Education but in a Faculty of Letters and Science.

Pedagogical formation briefly aims to give pedagogy training about their fields to those who have just studied a field subject as it is not enough to have knowledge on the field but to be able to teach it, also maintain a classroom management and etc. (Yıldırım \& Vural, 2014). Although the main aim of the Faculty of Science and Letters is to make research on science and train scientists and researchers, also produce new knowledge (Yüksel, 2010) and as teaching is seen as a specialization profession, the attainment of the qualities needed for this profession with short-term courses for students rather than being trained in Faculties of Education is seen as a problem by most of the academic circles.

The perspectives of the students attending the aforementioned course, rather than being trained 4 years just with the aim of being a teacher, on the academic staff training them can have clues reflecting their perspectives about the teaching profession. The positive perspectives on teaching help a teacher to better teach whereas the negative causes the opposite. Therefore, it is of great importance for the teacher candidates attending pedagogical formation program to have positive views on the academic staff who are their main role models as teachers. One of the ways to identify this is "metaphors".

Also referred to as similes, metaphors make a concept more interesting and comprehensible (Low, 2008, p. 212). 
The starting point of analyses through metaphors is the studies conducted by Lakoff and Johnson (1980) who studied the roles of metaphors in human cognition. As metaphors are believed to be a reliable means to uncover the unmentioned assumptions, the usage of metaphors in educational studies' methodologies has also been widespread. Metaphors in educational discourse are used as a means of revealing the beliefs and attitudes as well as a teaching technique (cited by Zheng \& Song, 2010, p. 42).

In recent years, metaphor studies in education field, as in the world, seem to be increased. Taking into account teacher-training field; we confront with various studies dealing with the metaphorical perceptions of the teacher candidates towards various concepts (Konaklı and Göğüş, 2013; Koşar, 2016; Koç, 2014; Tortop, 2013; Polat, Apak and Akdağ, 2013; Ocak and Gündüz, 2006; Saban, Koçbeker and Saban, 2006; Akbaba-Altun and Apaydın, 2013). However, when these studies are examined we see that "teacher candidates" are referred to as students who study teacher training in Faculties of education. Nevertheless, there is some increase in the number of the studies dealing with the metaphors of students who attend pedagogical formation certificate program (Dündar and Karaca, 2013; Yapıcı and Yapıcı, 2013; Nartgün and Gökçer, 2014; Nartgün and Özen, 2015; Özdemir and Erol, 2015; Taşgın and Küçükoğlu, 2015; Çocuk, Yokuş and Tanrıseven, 2015). But, studies dealing with the metaphorical conceptions of teacher candidates as both faculty of education students (Tortop, 2013; Polat, Apak and Akdağ, 2013; Koşar, 2016) and pedagogical formation program students (Kumral, 2009) on the academic staff training them is really scarce.

The roles of the academic staff, the most important actors of the universities, are of great importance in teacher training. Among the academic staff, those working in the faculties of education have distinct roles in pedagogical formation program as they serve for a training focused on teaching profession mission. In this respect, it is very important for the teacher candidates to have positive impressions on the academic staff training them and being a role model for them. Because these teacher candidates could be monitoring and taking them as role models in their future teaching profession.

When the related literature is investigated, metaphorical studies on the academic staff by these teacher candidates weren't found. With this study, it is believed that a unique contribution will be made to the literature by providing the metaphorical perceptions of the teacher candidates attending pedagogical formation program. In addition to this, it is aimed to find out what kind of metaphorical perceptions the teachers of the future have towards the academic staff who try to attain the basic mission of the teaching profession.

\subsection{The Aim of the Research}

The aim of this research is to reveal the metaphors of teacher candidates attending pedagogical formation program that last for a short time towards the academic staff. Answers to following questions were searched in line with this aim:

- What are the metaphors of the teacher candidates towards the academic staff?

- Which conceptual categories can these metaphors be grouped in?

\section{Method}

\subsection{Research Model}

The research was designed with qualitative model and phenomenology design was used (Yıldırım and Şimşek, 2011). Therefore, the focused phenomenon in this research is to describe how the teacher candidates conceptualize their thoughts about academic staff through metaphors.

\subsection{Study Group and Sample}

The study group of the research was composed of 3498 teacher candidates attending the Pedagogical Formation Certificate Program in Gazi University, Gazi Faculty of Education in 2015-2016 semester. The sample of the research was determined with simple random sampling method with 392 teacher candidates. As known, it is sufficient to include 350 people in the sample taking into account the \pm 0.05 mistake proportion according to $95 \%$ reliability level (Yazıcıŏglu \& Erdoğan, 2004, pp. 49-50). Therefore, 454 people were included into research with the likelihood that data loss may occur. But with the elimination of the data pre-analysis process, metaphors produced by 392 teacher candidates were taken into account. The distribution of the 392 teacher candidates forming the sample according to gender is seen in Table 1. 
Table 1. Participants' distribution according to gender

\begin{tabular}{ccc}
\hline Gender & $\mathrm{f}$ & $\%$ \\
\hline Female & 288 & 73.46 \\
Male & 104 & 26.54 \\
\hline Total & 392 & 100.00 \\
\hline
\end{tabular}

As seen, approximately three quarter $(73.46 \%)$ of the participants are female whereas the remaining one quarter $(26.54 \%)$ are male teacher candidates.

\subsection{Data Collection Tool}

For determining the metaphorical perceptions of the teacher candidates towards the academic staff, teacher candidates have been requested to fill in the sentence; "Academic staff during the pedagogical formation program is like .......; because .................." In the forms given to the teacher candidates the term metaphor was defined and an example metaphor sentence on the subject was given. They were asked to define "academic staff" term with one word and then explain the reason for their choice in the second part and present a justification. They were also asked for their demographic information such as gender. The basic data source of the research was the metaphor forms filled with the handwriting of the teacher candidates.

\subsection{Data Analysis and Interpretation}

The data analysis of the research was conducted with qualitative analysis. The data were analyzed with content analysis. The main objective of content analysis is to reveal the concepts that will explain the data and the relationship between these concepts. Therefore, the aim with content analysis is to gather the data that show similarities among themselves within the frame of concepts and themes and interpret them in accordance with the aims of the research (Yıldırım and Şimşek, 2011).

In addition, the frequencies of the concepts in scope of the produced metaphors were determined. The gathered data were transferred into computer and frequencies and percentages of the metaphors were identified in this respect.

The analysis and interpretation of the metaphors produced by the teacher candidates on the academic staff were realized in a five-stage process (Aydın, 2010; Saban 2004, 2008, 2008a; Yıldırım \& Şimsek, 2011). These stages are: (a) naming, (b) sortation (elimination and refining), (c) category formation, (d) validity and reliability and finally (e) transferring the data to computer and evaluation stage. These stages could be summarized as follows:

a. Naming stage: In this stage, firstly the produced metaphors were put into a list of alphabetical order. In forming the mentioned list the explicit formation of the metaphors were taken as a basis and all metaphors by the teacher candidates (e.g.: sculptor... and etc.) were coded.

b. Sortation (elimination and refining) stage: Metaphor analysis was made in the first place. While making metaphor analysis, basic principles of this analysis (Saban et al., 2006) and content analysis (Yıldırım \& Şimşek, 2011) were used together. Accordingly, the produced metaphors were examined according to (a) the subject of the metaphor, (b) the resource of the metaphor, and (c) the relationship between the subject and the resource of the metaphor. So, the metaphors were analyzed according to their common features.

Among all forms, 62 of them weren't in the convenient structure and evaluated as "poor metaphor", also the source and the reason of the metaphor was not specified, did not contribute to describing academic staff. So, these 62 forms were put out of examination. For example the sentences which didn't specify any metaphor source such as; "academic staff should train us as good teachers", "academic staff should present new information and give us the right to speak" and statements after "academic staff is like..." without any justification such as "academic staff is like a technic director" were eliminated. Moreover, statements containing more than one category such as "academic staff is like a book. Some give just the theoretical information everybody knows whereas some give the information in the book but unnoticed by the students so serve as a savior" were eliminated. In addition statements not contributing to describe academic staff or illogic expressions such as "academic staff is like a trinket because students go their own way" were also eliminated. After the required eliminations, 392 forms were taken into examination. Then, another alphabetical list was made. One each sample metaphor among the ones that present each metaphor the best was chosen and this choice was made with the common views of two experts. The reason for this is to (a) specify a sample metaphor on behalf of the metaphors formed under one category and (b) raise the validity process of the research.

c. Category forming stage: In this stage, the produced metaphors were categorized according to the features that 
reveal the perspectives of the teacher candidates about the academic staff. While making these categorizations, common analogies were formed together and produced the themes and these formed the basis to produce conceptual categories. According to this, 11 conceptual categories were formed. For example; metaphors in the scope of "academic staff as a resource of knowledge" indicated generally that the academic staff are the basic resources in reaching the knowledge and emphasized that they master knowledge. For instance, the statement: "academic staff is like Santa Claus. Because distributes knowledge to the students as gifts and students wait to get this knowledge enthusiastically" was evaluated in the relevant category.

d. Validity and reliability stage: In order for providing the validity of the research data analysis process was explained in detail and all metaphor explanations by the teacher candidates themselves were taken into account as a whole. For testing the reliability, metaphors formed in 11 categories were broached to two expert views whether they were classified in terms of their meanings they cover. Experts matched the metaphor list and the category list in which these metaphors took place. This matching was compared with that of the researchers. Miles and Huberman's (1994) reliability formula (Reliability = Consensus/ (Consensus + Dissensus) was used in making the comparisons which showed that only a very few metaphors were put into different categories by the experts. Experts and researchers gathered together and a whole consensus was achieved and reliability study was completed with $100 \%$ consensus.

e. Transferring the data to computer and evaluation stage: Metaphors and related categories the arrangement of which was done above were transferred to computer. By this way, the analyses about the measure of dispersion (f, \%) of the research was provided.

\section{Findings}

The findings obtained in the research are presented according to the aims of the research via tables below.

Metaphors produced by the teacher candidates attending the pedagogical formation program about the academic staff are seen in Table 2.

Table 2. The distribution of metaphors produced on “Academic Staff” (In alphabetical order)

\begin{tabular}{|c|c|c|c|c|c|c|c|}
\hline M.C. & Metaphor name & $\mathrm{f}$ & $\%$ & M.C. & Metaphor name & $\mathrm{f}$ & $\%$ \\
\hline 1 & A book & 1 & .30 & 43 & Car steering wheel & 1 & .30 \\
\hline 2 & A healing goldfish & 1 & .30 & 44 & Carpenter & 6 & 1.50 \\
\hline 3 & A lighthouse & 1 & .30 & 45 & Case & 1 & .30 \\
\hline 4 & A morphined tooth & 1 & .30 & 46 & Chameleon & 2 & .50 \\
\hline 5 & A painting & 1 & .30 & 47 & Cheetah & 2 & .50 \\
\hline 6 & Accelerated motor & 1 & .30 & 48 & Cleaner & 1 & .30 \\
\hline 7 & Accountant & 1 & .30 & 49 & Clock & 2 & .50 \\
\hline 8 & Adam and Eve & 1 & .30 & 50 & Coffee & 1 & .30 \\
\hline 9 & Address telling kiosk owner & 1 & .30 & 51 & Colors & 1 & .30 \\
\hline 10 & Adolf Hitler & 1 & .30 & 52 & Comedian & 1 & .30 \\
\hline 11 & Alluvium set lakes & 1 & .30 & 53 & Compass & 5 & 1.30 \\
\hline 12 & An angel & 1 & .30 & 54 & Computer & 3 & .80 \\
\hline 13 & An artist each & 1 & .30 & 55 & Confection & 1 & .30 \\
\hline 14 & Angel & 2 & .50 & 56 & Confectioner & 2 & .50 \\
\hline 15 & Ankara & 1 & .30 & 57 & Construction foreman & 2 & .50 \\
\hline 16 & Ant & 1 & .30 & 58 & Container & 1 & .30 \\
\hline 17 & Antenor & 3 & .80 & 59 & Cook & 3 & .80 \\
\hline 18 & Architect & 2 & .50 & 60 & Co-pilot & 1 & .30 \\
\hline 19 & Arrow mark & 1 & .30 & 61 & Copper embroidery craftsman & 1 & .30 \\
\hline 20 & Artist & 9 & 2.30 & 62 & Cotton & 1 & .30 \\
\hline 21 & Aspirin & 1 & .30 & 63 & Craftsman & 1 & .30 \\
\hline 22 & Babushka doll & 2 & .50 & 64 & Crochet needle & 1 & .30 \\
\hline 23 & Baker & 1 & .30 & 65 & Crossword puzzle & 1 & .30 \\
\hline 24 & Bakery & 2 & .50 & 66 & Crown cork opener & 1 & .30 \\
\hline 25 & Bat in the beehive & 1 & .30 & 67 & Deep sea & 1 & .30 \\
\hline 26 & Bee & 1 & .30 & 68 & Dictator & 1 & .30 \\
\hline 27 & Book & 8 & 2.00 & 69 & Dinosaurs & 1 & .30 \\
\hline
\end{tabular}




\begin{tabular}{|c|c|c|c|c|c|c|c|}
\hline 28 & Book worm & 1 & .30 & 70 & Director & 1 & .30 \\
\hline 29 & Bookmarker & 1 & .30 & 71 & Doctor & 3 & .80 \\
\hline 30 & Boundless sea & 1 & .30 & 72 & Dough master & 1 & .30 \\
\hline 31 & Brain & 2 & .50 & 73 & Dough roller & 1 & .30 \\
\hline 32 & Broken watch & 1 & .30 & 74 & Dried beans with rice & 1 & .30 \\
\hline 33 & Brother-sister & 1 & .30 & 75 & Driver & 4 & 1.00 \\
\hline 34 & Building contractor & 1 & .30 & 76 & Embroiderer & 1 & .30 \\
\hline 35 & Business person & 1 & .30 & 77 & Employee who put the bread in the & & \\
\hline 36 & Butterfly & 1 & .30 & & oven & 1 & .30 \\
\hline 37 & Calligraphist & 1 & .30 & 78 & Encyclopedia & 1 & .30 \\
\hline 38 & Camera & 1 & .30 & 79 & Engineer & 1 & .30 \\
\hline 39 & Candle & 9 & 2.30 & 80 & Equilateral triangle & 1 & .30 \\
\hline 40 & Capitalism & 1 & .30 & 81 & Example & 1 & .30 \\
\hline 41 & Car & 2 & .50 & 82 & Executive & 1 & .30 \\
\hline \multirow[t]{2}{*}{42} & Car mechanic & 1 & .30 & 83 & Expert resources & 1 & .30 \\
\hline & & & & 84 & Explorer & 1 & .30 \\
\hline 85 & Extraterrestrial & 1 & .30 & 144 & Mother & 2 & .50 \\
\hline 86 & Eye glasses & 2 & .50 & 145 & Mother-father & 3 & .80 \\
\hline 87 & Factory & 1 & .30 & 146 & Music & 1 & .30 \\
\hline 88 & Family members & 1 & .30 & 147 & Navigation & 1 & .30 \\
\hline 89 & Famous actor & 1 & .30 & 148 & Novel & 1 & .30 \\
\hline 90 & Farmer & 2 & .50 & 149 & Nutcracker & 1 & .30 \\
\hline 91 & Fire & 3 & .80 & 150 & Ocean & 1 & .30 \\
\hline 92 & Fired rocket & 1 & .30 & 151 & Orange & 1 & .30 \\
\hline 93 & Fish & 1 & .30 & 152 & Paintbrush & 1 & .30 \\
\hline 94 & Flower & 1 & .30 & 153 & Painting & 1 & .30 \\
\hline 95 & Fluid liquid & 1 & .30 & 154 & Papa Smurf & 1 & .30 \\
\hline 96 & Flying balloon & 1 & .30 & 155 & Parent & 4 & 1.00 \\
\hline 97 & Footballer & 1 & .30 & 156 & Parrot & 1 & .30 \\
\hline 98 & Friend & 2 & .50 & 157 & Pencil & 3 & .80 \\
\hline 99 & Garden & 1 & .30 & 158 & Perform & 2 & .50 \\
\hline 100 & Gardener & 6 & 1.50 & 159 & Performer & 2 & .50 \\
\hline 101 & Gastrologist & 1 & .30 & 160 & Personnel & 1 & .30 \\
\hline 102 & Google research engine & 3 & .80 & 161 & Philosopher & 3 & .80 \\
\hline 103 & Guide & 7 & 1.80 & 162 & Photocopier & 1 & .30 \\
\hline 104 & Gurgling river & 1 & .30 & 163 & Poet & 1 & .30 \\
\hline 105 & Guru & 1 & .30 & 164 & Polestar & 1 & .30 \\
\hline 106 & Hand lamp & 1 & .30 & 165 & Politician & 1 & .30 \\
\hline 107 & Heart & 1 & .30 & 166 & Preface of a book & 1 & .30 \\
\hline 108 & Heel spur & 1 & .30 & 167 & Presenter & 1 & .30 \\
\hline 109 & Helicopter & 1 & .30 & 168 & Psychologist & 3 & .80 \\
\hline 110 & Hero who saved the world & 1 & .30 & 169 & Puppet & 1 & .30 \\
\hline 111 & Household appliances & 1 & .30 & 170 & Radio & 1 & .30 \\
\hline 112 & Ideal & 1 & .30 & 171 & Rain & 1 & .30 \\
\hline 113 & Idol & 2 & .50 & 172 & Rainbow & 2 & .50 \\
\hline 114 & Imposter reverend & 1 & .30 & 173 & River & 1 & .30 \\
\hline 115 & Inspector Gadget & 1 & .30 & 174 & Robot & 5 & 1.30 \\
\hline 116 & Internet & 1 & .30 & 175 & Role model & 2 & .50 \\
\hline 117 & Ironmaster & 2 & .50 & 176 & Rowdy & 1 & .30 \\
\hline 118 & Kinder surprise & 1 & .30 & 177 & Rug handloom & 1 & .30 \\
\hline 119 & Kitchen appliance & 1 & .30 & 178 & Runner in the last 500 meters & 1 & .30 \\
\hline 120 & Kitchen sponge & 1 & .30 & 179 & Salt & 1 & .30 \\
\hline 121 & Lamp & 1 & .30 & 180 & Sand glass & 2 & .50 \\
\hline 122 & Lantern & 7 & 1.80 & 181 & Santa Claus & 1 & .30 \\
\hline 123 & Laws & 1 & .30 & 182 & Satellite & 1 & .30 \\
\hline 124 & Lemon & 1 & .30 & 183 & School counsellor & 1 & .30 \\
\hline
\end{tabular}




\begin{tabular}{|c|c|c|c|c|c|c|c|}
\hline 125 & Library & 2 & .50 & 184 & Scientist & 1 & .30 \\
\hline 126 & Light & 13 & 3.30 & 185 & Sculptor & 1 & .30 \\
\hline 127 & Light at the end of the tunnel & 1 & .30 & 186 & Seasons & 1 & .30 \\
\hline 128 & Lighthouse & 1 & .30 & 187 & Ship master & 1 & .30 \\
\hline 129 & Like gold dust & 1 & .30 & 188 & Snowflakes & 1 & .30 \\
\hline 130 & Lion & 3 & .80 & 189 & Soap & 1 & .30 \\
\hline 131 & Lovebird & 1 & .30 & 190 & Soccer ball & 1 & .30 \\
\hline 132 & Machine part & 1 & .30 & 191 & Socrates & 1 & .30 \\
\hline 133 & Malignant tumor cells & 1 & .30 & 192 & Soil & 5 & 1.30 \\
\hline 134 & Master & 3 & .80 & 193 & Sponge & 1 & .30 \\
\hline 134 & Medicine & 3 & .80 & 194 & Stack of ego & 1 & .30 \\
\hline 136 & Medieval drama players & 1 & .30 & 195 & Star in the sky & 1 & .30 \\
\hline 137 & Merchant & 1 & .30 & 196 & Stone hanging on my foot & 1 & .30 \\
\hline 138 & Mill & 1 & .30 & 197 & Storyteller & 1 & .30 \\
\hline 139 & Miner who labors & 1 & .30 & 198 & Streetlight & 1 & .30 \\
\hline 140 & Miners & 1 & .30 & 199 & Sun & 8 & 2.00 \\
\hline 141 & Mirror & 5 & 1.30 & 200 & Superman & 1 & .30 \\
\hline 142 & Mixer & 1 & .30 & 201 & Supermarket & 1 & .30 \\
\hline 143 & Moon & 3 & .80 & 202 & Supersonic & 1 & .30 \\
\hline 203 & Sustainability & 1 & .30 & 217 & Up-to-date information & 1 & .30 \\
\hline 204 & Swagger & 2 & .50 & 218 & Vitamin & 1 & .30 \\
\hline 205 & Teacher & 2 & .50 & 219 & Walking ego & 1 & .30 \\
\hline 206 & Technical director & 3 & .80 & 220 & Walking stick & 1 & .30 \\
\hline 207 & Television & 1 & .30 & 221 & Wall & 1 & .30 \\
\hline 208 & Tin & 1 & .30 & 222 & Walnut & 1 & .30 \\
\hline 209 & Traveler & 1 & .30 & 223 & Water & 6 & 1.50 \\
\hline 210 & Treasure & 2 & .50 & 224 & Watermelon & 1 & .30 \\
\hline 211 & Tree & 13 & 3.30 & 225 & Wind & 2 & .50 \\
\hline 212 & Tree in the forest & 1 & .30 & 226 & Window & 2 & .50 \\
\hline 213 & Tropical rain forest & 1 & .30 & 227 & Wise man & 1 & .30 \\
\hline 214 & Turkish criminal law & 1 & .30 & 228 & Wood & 1 & .30 \\
\hline 215 & Two sides of the same coin & 1 & .30 & 229 & Wooden & 1 & .30 \\
\hline 216 & Universal set & 2 & .50 & 230 & Yeast & 1 & .30 \\
\hline \multicolumn{6}{|c|}{ T O T A L } & 392 & 100.0 \\
\hline
\end{tabular}

M.C. $=$ metaphor code.

As seen in the table, teacher candidates attending the pedagogical formation program (392 students) produced 230 metaphors on the academic staff. Among these metaphors "tree" (13 students-3.3\%) and "light" (13 students-3.3\%) are on the first rank, the second is "candle" and "artist" (a total of $4.6 \%$ with 9 students) and "book" and "sun" ( 8 students and a total of $4 \%$ ) comes on the third rank. The associated phenomenon with the metaphors is presented in Table 3.

Table 3. The phenomenon associated with the Metaphors

\begin{tabular}{llcc}
\hline No. & Metaphor Phenomenon & $\mathrm{f}$ & $\%$ \\
\hline 1 & Object & 110 & 28.06 \\
2 & Occupation & 110 & 28.06 \\
3 & Nature & 45 & 11.47 \\
4 & Abstract concepts & 41 & 10.45 \\
5 & Family-friend-guide & 20 & 5.10 \\
6 & Animal & 15 & 3.82 \\
7 & Food-drink & 14 & 3.57 \\
8 & Person (real-imaginary) & 12 & 3.06 \\
9 & Drug-organ-illness & 11 & 2.80 \\
10 & Technology & 6 & 1.53 \\
\hline
\end{tabular}




\begin{tabular}{llcc}
\hline No. & Metaphor Phenomenon & $\mathrm{f}$ & $\%$ \\
\hline 11 & Concrete concepts & 4 & 1.02 \\
12 & City-place & 4 & 1.02 \\
& TOTAL & 392 & 100.00 \\
\hline
\end{tabular}

As seen above, among the metaphors produced, ones associated both object (110) and occupation (110) are in the first rank with $28 \%$. These are followed by nature (45) with $11.47 \%$ and abstract concept metaphors (41) with $10.45 \%$.

Findings obtained with the classification of the metaphors into categories are presented in the table below:

Table 4. Metaphors according to the categories and the ratio of the students producing the metaphors

\begin{tabular}{lll}
\hline Category name & Metaphors & $\mathrm{f}$ \\
\hline & Brother-sister (1), tree (2), Ankara, mother, mother-father (3), coach, car, car steering wheel, \\
& bat in the beehive, lion, aspirin, moon (2), walking stick, brain, a lighthouse, a book, \\
& chameleon, crossword puzzle, co-pilot, lighthouse, doctor (2), parent, employee who put the \\
& bread in the oven, hand lamp, miner who labors, lantern (7), philosopher, camera, soccer \\
& ball, ship master, traveler, eye glasses, sun (6), calligraphist, treasure, medicine (3), \\
& construction foreman, light (9), butterfly, bookmarker, Polestar, library, lamp, lemon, $127 \quad 32.40$ \\
& miners, carpenter (3), yeast, dough roller, architect, candle (5), guru, kitchen appliance, \\
1. Academic staff who leads, & navigation, teacher, arrow mark, medieval drama players, performer, confectioner, window, \\
guides and directs & psychologist (2), compass (4), guide (5), school counsellor, paintbrush, artist (5), novel, \\
& wind, artist, driver (4), water, technical director (2), soil, merchant, light at the end of the \\
& tunnel, salt, ideal, master, vitamin, director (79 metaphors)
\end{tabular}

Adam and Eve, address telling kiosk owner, tree, alluvium set lakes, mother, encyclopedia, fire, fired rocket, brain, wise man, computer (2), scientist, gurgling river, deep sea, 2. Academic staff as a boundless sea, equilateral triangle, factory, philosopher, rainbow, google research engine resource of knowledge and (3), sun, helicopter, light (2), pencil (3), rug handloom, book (7), sand glass, dried beans experience

3. Academic staff who is constructive and developer gastrologist, crown cork opener, eye glasses, dough master, sculptor, construction foreman, river, carpenter (3), architect, engineer, building contractor, embroiderer, tree in the forest, crochet needle, confectioner, compass, artist (3), craftsman, water (2), Superman, executive, (36 metaphors)

Tree (3), fluid liquid, car, bee, cook, lion, moon, garden, ant, two sides of the same coin,

4. Multi perspective, self-developing academic staff open to change

\begin{tabular}{l}
\hline $5 . \quad$ Respectful, patient, \\
tolerant and democratic \\
academic staff
\end{tabular}

6. Academic staff that is role
model and set an example

7. Academic staff just narrating, not communicating enough

8. Authoritative and
oppressive academic staff

chameleon, flower, personnel, universal set (2), philosopher, footballer, rainbow, up-to-date information, internet, snowflakes, book worm, malignant tumor cells, machine part, babushka doll (2), accountant, ocean, clock, runner in the last 500 meters, water, supermarket, sustainability, soil (3), rain (33 metaphors)

Tree, family members, friend (2), lion, an angel, walnut, doctor, sun, light, coffee, container, artist, Papa smurf, Socrates, water, soil, Turkish criminal law (24 metaphors)

Mirror (4), preface of a book, an artist each, parent (2), treasure, idol (2), explorer, example, (17 metaphors)

Candle (2), clock, computer, book, robot (3), accelerated motor, broken clock, mixer, sand dinosaurs, lovebird, supersonic, heart (19 metaphors)

Adolf Hitler, fire, kitchen sponge, dictator, wall, nutcracker, photocopier, rowdy, capitalism, watermelon, case, music, laws with rice, library, Angel, seasons, candle (2), Santa Claus, orange, guide (2), soap, streetlight, water, sponge, presenter, painting, wooden, cleaner, tropical rain forest, satellite, expert resources (47 metaphors)

Tree (6), coach, cook (2), fire, mirror, gardener (6), copper embroidery craftsman, a painting, farmer (2), mill, ironmaster (2), parent, household appliances, bakery (2), baker, angel, a morphined tooth, Inspector Gadget, car mechanic, cotton, psychologist, colors, performer, window, robot (2), role model (2), artist, poet, heel spur, famous actor, master $24 \quad 6.12$ glass, stone hanging on my foot, teacher, coach, technical director, parrot, cheetah, 225.61 


\begin{tabular}{|c|c|c|c|}
\hline $\begin{array}{l}\text { 9. Academic staff behaving } \\
\text { inconsistently } \\
\text { irresponsive }\end{array}$ & $\begin{array}{l}\text { Like gold dust, business person, puppet, politician, radio, wind, imposter reverend, } \\
\text { confection, kinder surprise, a healing goldfish, tin, extraterrestrial (12 metaphors) }\end{array}$ & 12 & 3.06 \\
\hline $\begin{array}{l}\text { 10. Non-communicative } \\
\text { academic staff with high ego }\end{array}$ & $\begin{array}{l}\text { Swagger (2), stack of ego, hero who saved the world, star in the sky, wood, flying balloon, } \\
\text { walking ego ( } 7 \text { metaphors) }\end{array}$ & 8 & 2.04 \\
\hline $\begin{array}{l}\text { 11. Academic staff using } \\
\text { effective body language and } \\
\text { presentation techniques }\end{array}$ & $\begin{array}{l}\text { Fish, cheetah, storyteller, light, comedian, television, master } \\
\text { (7 metaphors) }\end{array}$ & 7 & 1.79 \\
\hline 11 categories & 294 metaphors & 392 & 100,0 \\
\hline
\end{tabular}

As seen in the table, grouping was made in 11 categories. 7 categories including the positive thoughts of the students (338 students-86.467\%) and 4 categories (53 students-14.03\% reflecting the negative thoughts were formed. There are 294 metaphors. The reason why 230 metaphors were produced and presented in the previously presented Table 2 is that the reason the same metaphor to be presented and repeated in more than one category. For example, "sun" metaphor falls into the $1^{\text {st }}$ category with a frequency of 6 and in the $2^{\text {nd }}$ and the $5^{\text {th }}$ category with one each frequency. Therefore, "sun" metaphor was calculated 3 times in the formation of the metaphors. This is because each "sun" metaphor is explained with different metaphor justification. In other words, as different meanings are assigned to "sun" 3 metaphors are developed. This is the reason for the production of 294 metaphors in the research.

Findings on the metaphors according to categories were put together with the positive and negative behaviors. Categories 1-2-3-4-5-6-11 represent the positive behaviors whereas categories 7-8-9-10 represent a content of negative behaviors and were shown below in this order.

Category 1: Academic staff who leads, guides and directs

127 teacher candidates produced 79 metaphors in this category. $32.40 \%$ of them evaluated the academic staff as people who have the qualities of leading, guiding and directing. When metaphors are examined it is seen that they see the academic staff as people who give them different point of views, lighten up their future, give meaning to their lives, contribute to their progress in teaching profession and guide their future. Moreover, the academic staff is people who broaden their horizons, contribute to the solution of their problems, guide, prepare for life, interfere when needed, arouse interest and motivate them. Some remarkable statements in this respect are as follows:

Academic staff is like a streetlight. Because they have a very huge contribution to enlighten the darkness in the students that is due to ignorance (S31).

Academic staff is like a torch. Because they have a huge contribution to enlighten a dark road that a student have to go and help them find the exit the best way (S79).

Academic staff is like brain. Because they integrate their students'thoughts and behaviors (S379).

Category 2: Academic Staff as a Resource of Knowledge and Experience

In this category, 60 teacher candidates produced 47 metaphors. $15.31 \%$ of them see the academic staff as a resource of knowledge and experience. When the metaphors are examined we see that the academic staff transfer the knowledge the teacher candidates need, present them with new information and share their experiences with them. Moreover they present the current information and if needed correct the false learnings. Some of the views of the teacher candidates in this category are as follows:
Academic staff is like a pencil. Because they equip the students whom are blank plaque as if writing into a notebook (S49).
Academic staff is like a rainbow. Because they have various opinions same as the various and vivid colors of the rainbow. They reflect those colors to their students and form brand-new springs and give these new rainbows to the society ( $S 293$ ).
Academic staff is like the sun. Because just as the sun rises with a new hope, academic staff continue their education by a new hope every day to transfer their knowledge and experiences to their students (S315).

Category 3: Academic staff who is constructive and developer

55 teacher candidates produced 36 metaphors in this category. Accordingly, $14.03 \%$ of them evaluated academic staff as constructive and developer. When the produced metaphors are examined we see that the academic staff 
can plan learning, prepare the teacher candidates to life, train them as teachers beneficial to the society, sort of shape the raw material in their hands. In this respect, some definitions are:

Academic staff is like a mill. Because they labor, grind, grow, but the most important of all, wants us to be beneficial to the people and provide this (S65).

Academic staff is like a gardener. Because by watering, scything or pruning make them more productive in the nature. Students are a plant whereas academic staff are gardeners. They provide their students to participate in the society more productive by growing them (S114).

Academic staff is like a tree in the forest. Because for example tree first grows and becomes paper, then a pencil and a notebook. Therefore, academic staff shape both themselves and their students (S288).

Category 4: Multi perspective, self-developing academic staff open to change

According to the research findings, teacher candidates seem to evaluate the academic staff as "Multi perspective, self-developing and open to change". 39 of them (9.95\%) produced 33 metaphors in this respect. As the metaphors are examined, it is seen that academic staff always improve themselves with new information and are open to learning, also accommodate to the changes. Some explanations on this regard are as follows:

Academic staff is like continuity. Because their desire to learn and renovation of themselves never end (S272).

Academic staff is like the moon. Because with the new (current) information they learn with their own efforts everyday (always), brighten our darkening world (S326).

Academic staff is like malignant tumor cells. Because their accumulation of knowledge is limitless, they always improve themselves (S372).

Category 5. Respectful, patient, tolerant and democratic academic staff

The category in which the personal qualities of the academic staff are positively evaluated, 25 teacher candidates $(6.8 \%)$ produced 24 metaphors. Therefore, it can be said that the academic staff behave equally to the students, respect their personalities, answer their questions patiently and not be angry with them and act as leaders. Some of the definitions are:

Academic staff is like water. Because they are transparent as water. They are objective and unbiased when they teach (S227).

Academic staff is like an angel. Because they are always smiling, answering all our questions, never getting angry with us, as they know how education is, always behave well, like an angel, to us (S261).

Academic staff is like family member. Because they always approach patiently, affectionate and compassionate (S356).

Category 6. Academic staff that is role model and set an example

In this category, $6.12 \%$ of teacher candidates produced 17 metaphors. According to the metaphors produced in this context, academic staff are a good role model to the students especially in terms of teacher qualities. Some students take them as role models for being an effective teacher in the future. Some of the explanations in this respect are such:

Academic staff is like a mirror. Because when I look at them I can see my future life (S87).

Academic staff is like a famous actor. Because, we watch, admire them and try to be like them in the future (S191).

Academic staff is like a role model. Because students try to be like them with their behaviors and movements (S360).

Category 11. Academic staff using effective body language and presentation techniques

Among the positive behaviors of the academic staff are their usage of "effective body language and presentation techniques". 7 candidates $(1.79 \%)$ produced 7 metaphors in this category. They seem to be emphasizing that academic staff makes effective presentations in the classroom, use their body language effectively, and make the courses interesting. The views of two students are:

Academic staff is like TV. Because they are both moving and vocal (S16).

Academic staff is like a storyteller. Because they lecture the information by making it story rather than directly telling (S217). 
4 categories in which teacher candidates $(53,14.03 \%)$ define the academic staff as negative are summarized:

Category 7. Academic staff just narrating, not communicating enough

22 teacher candidates $(5.65 \%)$ produced 19 metaphors in this category. Academic staff seem to lecture just by narrating and without making any communication try to complete the curriculum. This is evaluated as boring and taking dislike from the course. Three views are as:

Academic staff is like a computer. Because they cannot be apart from computers and their presentations (S41).

Academic staff is like a book. Because they assume that we know everything they know. They forget that we are students. Some want us to learn without teaching. We are tested with what we do not know. Most of them teach us memorizing like a book. Our training is like memorizing (S50).

Academic staff is like supersonic. Because they lecture very fast. In order for completing the curriculum in time, there is always a hurriedness and fast lecture (S388).

Category 8. Authoritative and oppressive academic staff

13 teacher candidates composing $3.31 \%$ of all others produced metaphors defining the authoritarian and oppressive course environment of the academic staff. Even slightly at a few rate, this category should be paid attention to. Some academic staff takes firm stand on the students and produce an authoritative learning environment. Views on this category are:

Academic staff is like a dictator. Because they are so rough and strict. They are urgent with us in this limited course time. They don't understand us. They do what they want, not what we want. They are not understanding (S337).

Academic staff is like a rowdy. Because try to teach and present information forcibly. You cannot ask them anything (S341).

Category 9. Academic staff behaving inconsistently and irresponsive

Only 12 out of 392 teacher candidates (3.6 \%) evaluated the academic staff as inconsistent behaving, irresponsible and don't walk the talk by producing 12 metaphors. 2 of the explanations are:

Academic staff is like an imposter reverend. Because they don't do the things they say and teach. However,
want us to (S163).
Academic staff is like confection. Because you can't estimate whether they will react positively or negatively.
You can't know whether they are sweet or sour. They brush you off (S223).

Category 10. Non-communicative academic staff with high ego

Very few metaphors were produced in this category with negative academic staff behaviors (7 teacher candidates-7 metaphors). According to the explanations, candidates have problems in communicating with the academic staff and they cannot reach them. Academic staff characterized with high ego is very few. Two metaphors in this respect:

Academic staff is like a show-off. They don't do anything else but praise themselves (S197).

Academic staff is like a hero who saved the world. Because they are pompous. They are not reachable (S331).

\section{Results}

In this study aiming to explore the metaphorical perceptions of the pedagogical formation students about the academic staff, it is seen that the academic staff are described in 11 basic categories. Most of these categories are made of positive behaviors composing $86.47 \%$. These are respectively as shown in table 3 such as: 1 . guiding, advisor and counsellor, 2. academic staff as the resource of knowledge and experience, 3. constructive and developer, 4. multi-perspective, self-developing academic staff open to change, 5. respectful, patient, tolerant and democratic, 6. academic staff that is role model and set an example, 11, academic staff using effective body language and presentation techniques; dimensions. The remaining 4 categories are made of metaphors presenting the negative behaviors of academic staff and reflects the views of the $14.03 \%$ of teacher candidates. These categories are; 7. just narrating, not communicating enough, 8. authoritative and oppressive, 9. academic staff behaving inconsistently and irresponsive, 10. non-communicative academic staff with high ego. 


\section{Discussion}

According to the findings, approximately one third of the teacher candidates think that the academic staff lead and guide them about their future by making suggestions, and try to gain them different points of views. Besides, academic staff arise interest in the teacher candidates as well as motivate them and try to find solutions to their problems. In other words academic staff actualizes their roles as guiders, directors and leaders significantly. This finding is similar to the research of Tortop (2013, p. 156). Also in this study, the metaphors prepared by the teacher candidates are "academic staff who leads, guides and directs" and "academic staff as raiser". Koşar's (2016, p. 121) research also revealed that one third of the teacher candidates' produced metaphors such as "guiding", "counseling" and "developer beings". Similarly, Polat et al.'s (2013) research revealed that 7.2\% of teacher candidates stressed the guiding feature of the academic staff and shows similarity with the findings of the relevant research. As Anık and Oğur (2003) states, an academic staff should both train and prepare the students to life and the profession as well as be guider for their future and contribute for their success (Collins-Baş, 2002; Tunca et al., 2015).

Among the positive behaviors observed by the teacher candidates about the faculty of education academic staff is their being the resource of knowledge and experience. According to the findings; the academic staff can transfer new and comprehensive knowledge to the teacher candidates as well as share their experiences with students as well as play a role in correcting their false learnings. Hence, in the researches conducted by Polat et al. (2013), Tortop (2013) and Koşar (2016), teacher candidates emphasized the qualities of the academic staff as being the resource and transmitter of knowledge. So, all these show parallelism with the findings of this research.

Another positive aspect of the academic staff for the teacher candidates is that they play a developer and raiser role. They prepare the teacher candidates to the profession, train, and structure as teachers beneficial to the society. It is a positive finding that the academic staff plays a developer role for the teachers of the future in their pre-service education. Parallel with the findings of the research, Koşar (2016) also pointed out that teacher candidates used the metaphors; developer and raiser for the academic staff.

It is of great importance for the academic staff who are training teachers to be open to new ideas and monitor the developments closely for the training of teacher candidates. Collins-Baş (2002) referred to literature on the subject and stressed that among the qualities of a good academic staff is to be open to diversity. In this study, it is also seen that among the positive views of teacher candidates towards the academic staff is that they are innovative, open to change and developing themselves. We confront a similar finding with that of Aslan and Yakar (2012). Teacher candidates stated that academic staff are innovative, keeping up with technology and developing themselves.

According to the personality qualities category produced by the teacher candidates, it can be said that academic staff treat them equally, show respect to their personalities and behave patiently. Moreover, leadership qualities are also among the stated positive qualities. Additionally another positive quality stated in another category is that they are serving as a model to the students and some students take them as role models. If teachers are required to create a democratic classroom environment, behave patiently and tolerantly to the students and display effective leadership behaviors it is important to train teachers in that way. It is a positive finding that according to the results of the study the academic staff seems to have these qualities. According to the results of a similar study conducted by Kaya, Taşdan, Kop, and Metin (2012), teacher candidates think that the academic staff displays democratic behaviors. In this respect, the study seems similar with the study of Kaya et. al. In the study conducted by Turturean in 2009; among the important qualities an academic staff should have is the ethical and moral behaviors (cited by Turturean, 2013). This finding is parallel is with the study. In the study of Nartgün and Özen (2015) done with the teacher candidates taking pedagogical formation program, it is seen that an ideal academic staff should be patient, idealist, understanding and a person to be role model for the students which shows parallelism with this study.

Even a little, some of the academic staff largely present their courses with lecture method and try to complete the planned curriculum without communicating enough. This could be an inconvenience for the teacher candidates to be trained with this very few number academic staff as they are expected to create a classroom environment with constructivist approach and train their students in an active learning environment. Because, teacher candidates could take these kinds of behaviors of the academic staff as a role model and can behave the same themselves. As stated by Özgüngör and Duru (2014) and Ergün, Duman, Kınca, and Sarıbaş (1999) the academic staff should develop themselves in terms of quality in parallel with the rapid changes and instead of just transferring the information and should take the facilitator role for their students to reach the information themselves, process the information with cognitive processes and evaluate it. Moreover, they should make their 
lessons more interesting and attractive by using various activities. We confront a similar finding in the study of Şen and Erişen (2002) in terms of showing an effective academic staff as a teacher who doesn't transfer information directly but helps the students to reach the information themselves. It is so obvious that lecture method is not sufficient in attaining the desired qualities to the students as well as increases the quality of the academic staff training the teachers of the future. In this respect, findings of the studies conducted by Aksu, Çivitçi, and Duy (2008) and İlter (2014) show parallelism with regard that academic staff mainly teaches with lecture method without enough communicating with the students.

Although with a very low rate, some teacher candidates evaluate the academic staff as oppressive and authoritarian. A very few academic staff can exhibit inconsistent behaviors, underestimate their students and create communication barriers. The reality that academic staff will be a role model for the teachers of the future who will attain very important missions and affect the quality of the educational process require the academic staff not to have negative behaviors. Similarly, in Eker's (2016) study students think that academic staff behave oppressive and authoritarian to them, which shows parallelism with the findings of this study. Once again Kumral (2009) states that the metaphorical perceptions of the teacher candidates towards the academic staff show more negative aspects than positive aspects and specifies these negative behaviors as behaving impolitely to the students with hardline. Although this research seems to have similar findings in terms of the qualities of the negative behaviors, it differs in terms of the rate of the negative behaviors over positive ones.

The knowledge and skills of a teacher in teaching and learning process is surely of great importance. However, it is difficult for teachers to be beneficial to the students if they cannot act as is expected from an effective teacher; in other words who is authoritarian, doesn't value the students and has communication problems. Teachers having these kinds of qualities cannot be beneficial to their students even if they high-level knowledge and skills. Ergün et al. (1999) and Nartgün and Özen (2015) also conducted a similar study with the similar findings; university students and teacher candidates wished for ideal academic staff who don't oppress but respect them; are pally with them and therefore respected and trusted by the students and also who communicate well with their verbal and non-verbal behaviors. In our study, even with a very few rate, some academic staff seem to have negative behaviors according to the teacher candidates.

\section{Suggestions}

According to the findings obtained, the fact that the Faculty of Education academic staff considerably exhibit positive behaviors should be shared with the other academic staff as a part of the organizational culture.

All the same, some consciousness studies could be made for changing the even a little negative behavior into positive. For this reason, some in-company trainings, seminars, conferences can be organized.

Another study that will examine the metaphorical perceptions of the Faculty of Education students towards the academic staff could be made for the comparison of metaphorical perceptions of the pedagogical formation students and the aforementioned students. So that it could be seen whether the role model qualities of the academic staff differ according to the different programs they work in.

\section{References}

Akbaba-Altun, S., \& Apaydın, Ç. (2013). Kız ve erkek öğretmen adaylarının "eğitim" kavramına ilişkin metaforik algıları. Kuram ve Uygulamada Eğitim Yönetimi, 19(3), 329-354. Retrieved from http://www.kuey.net/index.php/kuey/article/view/969

Aksu, M. B., Çivitçi, A., \& Duy, B. (2008). Yükseköğretim öğrencilerinin öğretim elemanlarının ders uygulamaları ve sınıf içi davranışlarına ilişkin görüşleri. Inönü Üniversitesi Eğitim Fakültesi Dergisi, 9(16), 17-42. Retrieved from http://efdergi.inonu.edu.tr/article/view/5000004228

Anık, S., \& Oğur, A. (2003). Bir üniversite hocası nasıl olmalı ve ondan beklenenler. SAÜ Fen Bilimleri Enstitüsü Dergisi, 7(1), 60-61. Retrieved from http://dergipark.gov.tr/saufenbilder/issue/20691/221082

Aslan, M. \& Yakar, A. (2012). Öğretmen adaylarının öğretim elemanı niteliklerine ilişkin bilişsel kurguları: Karşılaştırmalı bir inceleme. İlköğretim Online, 11(4), 1036-1052. Retrieved from http://dergipark.ulakbim.gov.tr/ilkonline/article/view/5000037839

Aydın, F. (2010). Ortaöğretim öğrencilerinin coğrafya kavramına ilişkin sahip oldukları metaforlar. Kuram ve Uygulamada Eğitim Bilimleri / Educational Sciences: Theory \& Practice, 10(3), 1293-1322. Retrieved from http://www.kuyeb.com/pdf/tr/5658248803195b55fd1 faef0dbbf0a31nFULL.pdf

Collins-Baş, A. (2002). Üniversite öğrencileri öğretim elemanlarının başarısını değerlendirebilir mi? İkilemler ve problemler. Ankara Üniversitesi Eğitim Bilimleri Fakültesi Dergisi, 35(1-2), 81-91. Retrieved from 
http://dergiler.ankara.edu.tr/dergiler/40/137/963.pdf

Çocuk, H. E., \& Yokuş, G.; Tanrıseven, I. (2015). Pedagojik formasyon öğrencilerinin öğretmenliğe ilişkin özyeterlik ve metaforik algıları: Mersin Üniversitesi örneği. Mustafa Kemal Üniversitesi Sosyal Bilimler Enstitüsü Dergisi, 12(32), 373-387. Retrieved from http://sbed.mku.edu.tr/article/view/5000146638

Dündar, H., \& Karaca, E. T. (2013). Formasyon öğrencilerinin “pedagojik formasyon programı”na ilişkin sahip oldukları metaforlar. Gazi Üniversitesi Endüstriyel Sanatlar Eğitim Fakültesi Dergisi, 30, 19-34. Retrieved from http://dergipark.ulakbim.gov.tr/esef/article/view/5000091876

Eker, D. (2016). Üniversite öğrencilerinin gözüyle sınıf içi olumsuz öğretim elemanı davranışları. Uluslararası Sosyal Araştırmalar Dergisi, 9(45), 564-571. Retrieved from http://www.sosyalarastirmalar.com/cilt9/sayi45_pdf/5egitim/eker_derya.pdf

Ergün, M., Duman, T., Kıncal, R. Y., \& Arıbaş, S. (1999). İdeal bir öğretim elemanının özellikleri. Afyon Kocatepe Üniversitesi Sosyal Bilimler Dergisi, 3, 1-11. Retrieved from http://acikerisim.aku.edu.tr

İlter, İ. (2014). Öğretim elemanlarının kullandığı yöntem ve tekniklere ilişkin öğretmen adaylarının görüşleri. Uluslararası Sosyal Araştırmalar Dergisi, 7(35), 562-575. Retrieved from http://www.sosyalarastirmalar.com/cilt7/sayi35_pdf/7egitim/ilter_ilhan.pdf

Kaya, H. İ., Taşdan, M., Kop, Y. \& Metin, M. (2012). Öğretmen adaylarının öğretim elemanlarının demokratik davranışlarına ilişskin algıları (Kars ili örneği). Pegem Ĕgitim ve Öğretim Dergisi, 2(1), 39-49. https://doi.org/10.14527/C2S1M4

Koç, E. S. (2014). Sınıf öğretmeni adaylarının öğretmen ve öğretmenlik mesleği kavramlarına ilişkin metaforik algıları. İnönü Üniversitesi Eğitim Fakültesi Dergisi, 5(1), 47-72. https://doi.org/10.17679/iuefd.79408

Konaklı, T., \& Göğüş, N. (2013). Öğretmen adaylarının eğitim fakültesine ilişkin metaforik algıları: Kocaeli Üniversitesi Eğitim Fakültesi örneği. International Journal of Human Sciences, 10(2), 68-93. Retrieved from https://www.j-humansciences.com/ojs/index.php/IJHS/article/viewFile/2617/1167

Koşar, D. (2016). Öğretmen adaylarının üniversite ve öğretim elemanı kavramlarına ilişkin metaforik algıları. International Online Journal of Educational Sciences, 8(3), 113-127. https://doi.org/10.15345/iojes.2016.03.011

Kumral, O. (2009). Öğretmen adaylarının öğretim elemanlarının davranışlarına yönelik algıları. Pamukkale Üniversitesi Eğitim Fakültesi Dergisi, 1(25), 92-102. Retrieved from http://pauegitimdergi.pau.edu.tr/Makaleler/926017637_Orhan\%20Kumral1.pdf

Low, G. (2008). Metaphor and education. In Ed. R. W. Gibbs Jr. (Ed.), The Cambridge Handbook of Metaphor and Thought. UK: Cambridge University Press. https://doi.org/10.1017/CBO9780511816802.014

Miles, M. B. \& Huberman, A. M. (1994). An Expanded Sourcebook Qualitative Data Analysis. Thousand Oaks, California: Sage Publications.

Nartgün, Ş, S., \& Gökçer, İ. (2014). Pedagojik formasyon eğitimi alan öğretmen adaylarının mesleklerine, geleceklerine, istihdamlarına ve eğitim politikalarına ilişkin metaforik algıları. E-International Journal of Educational Research, 5(4), 57-69. https://doi.org/10.19160/e-ijer.56142

Nartgün, Ş. S., \& Özen, R. (2015). Investigating pedagogical formation students' opinions about ideal teacher, teaching profession, curriculum, responsibility, public personnel selection examination (ppse) and employment: A metaphor study. Procedia - Social and Behavioral Sciences, 174, 2674-2683. https://doi.org/10.1016/j.sbspro.2015.01.951

Ocak, G., \& Gündüz, M. (2006). Eğitim fakültesini yeni kazanan öğretmen adaylarının öğretmenlik mesleğine giriş dersini almadan önce ve aldıktan sonra öğretmenlik mesleği hakkındaki metaforlarının karşılaştırılması. Afyon Kocatepe Üniversitesi Sosyal Bilimler Dergisi, 8(2), 293-310. Retrieved from http://acikerisim.aku.edu.tr/xmlui/handle/11630/3615

Özdemir, T. Y., \& Erol, Y. C. (2015). Pedagojik formasyon eğitimi alan öğretmen adaylarının okul, öğretmenlik ve öğrenci kavramlarına ilişkin algıları. CBÜ Sosyal Bilimler Dergisi, 13(4). https://doi.org/10.18026/cbusos.48652

Özgüngör, S., \& Duru, E. (2014). Öğretim elemanları ve ders özelliklerinin öğretim elemanlarının performanslarına ilişkin değerlendirmelerle ilişkileri. Hacettepe Üniversitesi Eğitim Fakültesi Dergisi, $29(2)$, 175-188. Retrieved from http://www.efdergi.hacettepe.edu.tr/yonetim/icerik/makaleler/87-published.pdf 
Polat, S., Apak, Ö., \& Akdağ, M. (2013). Sınıf öğretmeni adaylarının akademisyen kavramına ilişkin algılarının metafor analizi yoluyla incelenmesi. İnönü Üniversitesi Ĕgitim Fakültesi Dergisi, 14(2), 57-78. Retrieved from http://efdergi.inonu.edu.tr/article/view/5000004117/5000007784

Saban, A. (2004). Giriş düzeyindeki sınıf öğretmeni adaylarının "öğretmen” kavramına ilişkin ileri sürdükleri metaforlar. Türk Ĕ̈itim Bilimleri Dergisi, 2(2), 131-155.

Saban, A. (2008). Okula ilişkin metaforlar. Kuram ve Uygulamada Eğitim Yönetimi, 55, 459-496. Retrieved from http://dergipark.ulakbim.gov.tr/kuey/article/view/5000050616

Saban, A. (2008a). İlköğretim I. kademe öğretmen ve öğrencilerinin bilgi kavramına ilişkin sahip oldukları zihinsel imgeler. Ilkögretim Online, 7(2), 421-455. Retrieved from http://dergipark.ulakbim.gov.tr/ilkonline/article/view/5000038255

Saban, A., Koçbeker, B. N., \& Saban, A. (2006). Öğretmen adaylarının öğretmen kavramına ilişkin algılarının metafor analizi yoluyla incelenmesi. Kuram ve Uygulamada Eğitim Bilimleri, 6(2), 461-522. Retrieved from http://www.kuyeb.com/pdf/tr/dacaba6b44a2b44687062a156a7ded47antam.pdf

Şen, H. Ş., \& Erişen, Y. (2002). Öğretmen yetiştiren kurumlarda öğretim elemanlarının etkili öğretmenlik özellikleri. G.Ü. Gazi Ĕgitim Fakültesi Dergisi, 22(1), 99-116.

Taşgın, A., \& Küçükoğlu, A. (2015). Pedagojik formasyon programı öğrencilerinin “öğretmen” kavramına ilişkin metaforik algılarının incelenmesi. 24. Ulusal Eğitim Bilimleri Kongresi, 16-18 Nisan 2015, Niğde.

Tortop, H. S. (2013). Öğretmen adaylarının üniversite hocası hakkındaki metaforları ve bir değerlendirme aracı olarak metafor. Yüksekögretim ve Bilim Dergisi, 3(2), 153-160. https://doi.org/10.5961/jhes.2013.070

Tunca, N., Alkın Şahin, S., Oğuz, A., \& Güner, H. Ö. B. (2015). Qualities of ideal teacher educators. Turkish Online Journal of Qualitative Inquiry, 6(2), 122-148. https://doi.org/10.17569/tojqi.48192

Turturean, M. (2013). University trainers' key competencies - A global profile. Procedia - Social and Behavioral Sciences, 76, 801-805. https://doi.org/10.1016/j.sbspro.2013.04.209

Yapıcı, M., \& Yapıcı, Ş. (2013). Öğretmen adaylarının pedagojik formasyona ilişkin metaforları. Turkish Studies, 8(8), 1421-1429. https://doi.org/10.7827/TurkishStudies.5338

Yazıcıoğlu, Y., \& Erdoğan, S. (2004). SPSS uygulamalı bilimsel araştırma yöntemleri. Ankara: Detay.

Yıldırım, A., \& Şimşek, H. (2011). Sosyal bilimlerde nitel araştırma yöntemleri (8th ed.). Ankara: Seçkin Yayıncilık.

Yıldırım, İ., \& Vural, Ö. F. (2014). Türkiye'de öğretmen yetiştirme ve pedagojik formasyon sorunu. Journal of Teacher Education and Educators, 3(1), 73-90. Retrieved from http://jtee.org/document/issue5/MAK4.pdf

Yüksel, S. (2010). Türk üniversitelerinde eğitim fakülteleri ve ögretmen yetiştirme. Ankara: Pegem Akademi.

Zheng, H-b., \& Song, W-j. (2010). Metaphor analysis in the educational discourse: A critical review. US-China Foreign Language, 8(9), 42-49. Retrieved from http://files.eric.ed.gov/fulltext/ED514704.pdf

\section{Notes}

Note 1. This study is the expanded version of the proceeding presented in the $3^{\text {rd }}$ International Eurasian Educational Research Congress, May 31- June 3, 2016 in Muğla, Turkey.

\section{Copyrights}

Copyright for this article is retained by the author(s), with first publication rights granted to the journal.

This is an open-access article distributed under the terms and conditions of the Creative Commons Attribution license (http://creativecommons.org/licenses/by/4.0/). 